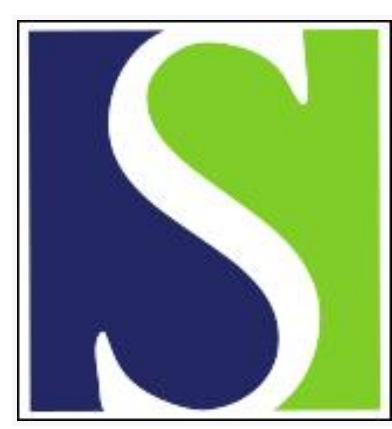

Scand J Work Environ Health 1982;8(3):209-221

https://doi.org/10.5271/sjweh.2482

Issue date: Sep 1982

Chromosome changes in workers (smokers and nonsmokers) exposed to automobile fuels and exhaust gases.

by Fredga K, Davring L, Sunner M, Bengtsson BO, Elinder CG, Sigtryggsson $P$, Berlin M

This article in PubMed: www.ncbi.nlm.nih.gov/pubmed/6186020 


\title{
Chromosome changes in workers (smokers and nonsmokers) exposed to automobile fuels and exhaust gases
}

\author{
by Karl Fredga, PhD, ${ }^{1}$ Lars Dävring, PhD, ${ }^{1}$ Margareta Sunner, FK, ${ }^{1}$ \\ Bengt $O$ Bengtsson PhD, ${ }^{1}$ Carl-Gustaf Elinder, MD, ${ }^{2}$ Per Sigtryggsson, MD, ${ }^{2}$ \\ Maths Berlin, MD
}

\begin{abstract}
FREDGA K, DÄVRING L, SUNNER M, BENGTSSON BO, ELINDER C-G, SIGTRYGGSSON P, BERLIN M. Chromosome changes in workers (smokers and nonsmokers) exposed to automobile fuels and exhaust gases. Scand $j$ work environ health 8 (1982) 209-221. The incidence of chromosome changes in men occupationally exposed to automobile fuels and exhaust gases was investigated. Blood samples were taken from the following four groups of 12 men: drivers of diesel-engine trucks, drivers of gasoline-engine trucks, automobile inspectors, and a reference group. The men in the groups were matched with respect to age, smoking habits, and length of time in their respective jobs. Chromosome preparations from lymphocytes were made and analyzed by standardized routine methods, and the frequencies of gaps, breaks, and sister chromatid exchanges were recorded. Statistical analysis of the results gave no evidence for a marked occupational effect, though there remains a grave suspicion that working with diesel motors may cause an increased level of chromosome changes. Smokers showed a significant or near significant increase in breaks, total aberrations, and sister chromatid exchanges over the nonsmokers in three of the groups. An analysis of the data revealed a weak positive correlation between the frequencies of chromosome breaks and sister chromatid exchanges in an individual.
\end{abstract}

Key terms: chromosome aberrations, diesel, gasoline, occupational exposure, sister chromatid exchanges.

Several investigations have shown that an increased incidence of chromosome aberrations occurs in occupational groups handling certain types of chemicals (12). Although no definite connection between these chromosome changes and the development of cancer has been established, a number of carcinogenic substances has proved to give rise to chromosome changes. Benzene is an example of a substance that can produce an increased in-

1 Institute of Genetics, University of Lund, Lund, Sweden.

2 Department of Environmental Hygiene of the Karolinska Institute and the National Institute of Environmental Medicine, Stockholm, Sweden.

3 Institute of Environmental Health, University of Lund, Lund, Sweden.

Reprints requests to: Prof K Fredga, Department of Genetics, University of Uppsala, Box 7003, S-750 07 Uppsala, Sweden. cidence of chromosome aberrations and has also been reported to have a carcinogenic potential (28).

We have previously investigated the benzene exposure (4) and incidence of chromosome changes (9) among workmen occupationally exposed to atmospheric concentrations of benzene higher than those encountered by the general public. Three groups of men handling gasoline were studied, namely, road tanker drivers, coastal tanker crews, and filling station attendants. A group of men engaged in the distillation of benzene was also studied. A significant increase in the incidence of chromosome changes was observed in the workers at the benzene distillation plant, but, of the gasoline workers, only the road tanker drivers showed such an increase. The tanker crews were occasionally exposed to higher benzene 
levels, but their long-term integrated exposure was less. It seems unlikely that the effect seen in the road tanker drivers was due to exposure to benzene, for, although the result was confirmed for another group of road tanker drivers conveying gasoline, the same effect was observed in drivers of tankers conveying milk. These results suggested that the chromosome changes observed in the drivers of road tankers were not due to exposure to benzene but were, in some way, associated with the driving of dieselpowered vehicles. An alternative hypothesis is that these changes are observed in those exposed to heavy traffic involving both gasoline and diesel vehicles. A further investigation has now been undertaken to test these two hypotheses, and also to assess the influence of the smoking habits of the subjects.

\section{Subjects and methods}

\section{Groups investigated}

Four groups of 12 men were selected for the investigation by means of a questionnaire. Information was requested on present and past employment, and also on exposure to factors that might bring aboui chromosome changes, eg, contact with solvents and other chemicals, smoking habits, radiographic examinations, and recent viral infections. The men in the groups were matched as far as possible with relation to age, length of time at work, and smoking habits; details are shown in tables 1-4. Each group contained six smokers and six nonsmokers.

Diesel vehicle drivers. Drivers of diesel vehicles were approached through their trade union. All of the men selected worked for the same organization and drove heavy trucks $(8-10 \mathrm{t})$.

Gasoline vehicle drivers. The main concern in the selection of drivers of gasoline-powered vehicles was that they should not have previously been employed on diesel vehicles. On account of the difficulty in tracing men with a diesel-free background, this group was not as homogeneous as the diesel group. The following three different types of gasoline vehicles were involved: light vehicles for short hauls (Ford Taunus, Volkswagen van) (4 men), light 8-cylinder vehicles for longer journeys (5 men), private cars in taxi service (3 men).

Mixed exposure group. Inspectors involved in automobile testing were selected from a group of volunteers submitted by their trade union. On the average, $90 \%$ of the exhaust gases to which these men were exposed came from gasoline engines, and $10 \%$ from diesel engines.

Reference group. The referents were selected partly from office workers employed outside the center of Stockholm and partly from guards at the Stockholm prison. One-half of the referents traveled to their work by automobile.

Another six men were also investigated at the same time, but the results from them were used only when the relationship between chromosome aberrations and sister chromatid exchanges (SCEs) was studied.

\section{Chromosome preparations}

Blood samples were collected from the subjects in 10-ml Vacutainers during May and June 1978. They were sent to the laboratory in batches of 12 , three from each of the four groups. All samples were analyzed for chromosome aberrations and SCEs. Lymphocytes were cultured and harvested by the routine standard method of our laboratory (9). Cultures were prepared by a micromethod and were initiated within $24 \mathrm{~h}$ of sampling; the medium was McCoy's 5a with $20 \%$ fetal calf serum, and phytohemagglutinin was used as the mitogen. The cultures were harvested after $72 \mathrm{~h}$ for the analysis of chromosome aberrations; fixation was preceded by hypotonic and colchicine treatments. The air-dried preparations were stained with Giemsa.

For the SCE analyses 5-bromodeoxyuridine (BrdU) was added initially to the cultures at concentrations of 3 and 30 $\mu \mathrm{g} / \mathrm{ml}$. The cells were grown in total darkness and harvested (fixed) in the usual manner after $74.5 \mathrm{~h}$. The preparations were stained in alkaline Giemsa without previous "Hoechst 33258"-staining and ultraviolet activation (1). We obtain- 
ed the best result after 6 min of staining at room temperature in a $3 \%$ solution of Giemsa (Merck) in $0.3 \mathrm{M}$ sodium phosphate, adjusted with $1 \mathrm{~N}$ sodium hydroxide to $\mathrm{pH} 10.6$.

\section{Chromosome analyses}

The slides were analyzed blind, that is, the investigators were unaware of the occupation, smoking habits, or medical history of the subjects. The same experienced person performed all the analyses, and all aberrant, as well as doubtful, cells were further checked by another trained cytogeneticist.

In the study of chromosome aberrations, 200 cells from each subject were analyzed under the microscope. Special attention was directed to the $A, D$, and $G$ group chromosomes in order that any possible rearrangements of a stable nature would be discovered. The recommendations given by Buckton \& Evans (5) were followed for the classification of aberrant cells.

The SCE analyses were also performed directly under the microscope; 20 cells from each subject were scrutinized, which involved as a rule 100-200 SCEs per individual. Only cells with 46 chromosomes (with the exception of cells with 47 chromosomes from one $46 / 47$ mosaic) and with a distinct differential staining of the two chromatids were included in the analyses. Terminal SCEs were classified as a single exchange, interstitial as two. SCEs in the centromeric region were included.

All analyses with the exception of 11 were based on cultures treated with a BrdU concentration of $30 \mu \mathrm{g} / \mathrm{ml}$. With these 11 subjects the cultures containing BrdU in a concentration of $30 \mu \mathrm{g} / \mathrm{ml}$ failed for unknown reasons, and cultures treated with BrdU in a concentration of $3 \mu \mathrm{g} / \mathrm{ml}$ were analyzed instead. These cultures represented a random subset of our sample; in other words, all four occupational groups were represented among the 11 exceptions. Both of the concentrations used were relatively low, and comparative studies of the SCE frequency in three individuals at the two BrdU concentrations revealed no marked difference. No distinction was therefore made with respect to the BrdU concentrations in the further analysis.

\section{Statistical analyses}

Nonparametric methods were used for all the statistical comparisons; these tests are not based on the assumption that the values follow a normal distribution. In order to establish whether a specified group was significantly different from the other three groups, or whether an observed difference could be due to chance, a special test was devised. The test is an extension of the sign test and is similar to Friedman's two-way analysis of variance (27). The details of the test are described in appendix 2 of Fredga et al (8).

\section{Results}

\section{Chromosome aberrations}

The results of the chromosome analyses are presented in tables $1-4$. These tables are divided into smokers and nonsmokers and give the age and length of employment in the job for individual subjects and also the frequency of aberrant cells and the frequency and type of chromosome aberrations. The aberrations were divided into gaps and breaks, further subdivided into chromatid and chromosome type. The results in tables $1-4$ are summarized in table 6 (along with the data of table 5) and fig 1.

The majority of the breaks was registered as acentric fragments. Only one cell with a chromatid interchange and six with dicentric chromosomes were encountered in the 9,600 cells analyzed. No ring chromosomes were observed in this investigation.

The highest frequency of breaks (group mean) was found for the nonsmoking diesel vehicle drivers and the gasoline vehicle drivers that smoke $(3.6 / 100$ cells $)$. The nonsmoking gasoline vehicle drivers and nonsmoking referents showed the lowest frequency of breaks (1.4). The highest and lowest frequency of total aberrations (breaks + gaps) was found for the automobile inspectors that smoke (9.0) and the nonsmoking referents (4.4), respectively.

One of the subjects in table 2, a gasoline vehicle driver who smoked, was a chromosome mosaic. He showed a small chromosome in excess of the 46 normal in $82.5 \%$ of his lymphocytes. This chromo- 
some was seen in both the 48- and 72-h cultures and also in the BrdU experiment, so it cannot be regarded as an in vitro artifact. The chromosome was a metacentric with active nucleolar organizing regions (silver-nitrate staining) terminally at both arms. It is likely that its arms correspond to the short arms of two D or G group

Table 1. Chromosome aberrations in the drivers of diesel vehicles (group 1); 200 cells were analyzed from each subject.

\begin{tabular}{|c|c|c|c|c|c|c|c|c|c|c|}
\hline & \multirow{3}{*}{$\begin{array}{l}\text { Age } \\
\text { (a) }\end{array}$} & \multirow{3}{*}{$\begin{array}{c}\text { Time } \\
\text { in job } \\
(a)\end{array}$} & \multirow{3}{*}{$\begin{array}{c}\text { Cells } \\
\text { with } \\
\text { aberr- } \\
\text { rations } \\
(\%)\end{array}$} & \multicolumn{4}{|c|}{ Type of aberration } & \multirow{3}{*}{$\begin{array}{l}\text { Total } \\
\text { gaps } \\
(\%)\end{array}$} & \multirow{3}{*}{$\begin{array}{c}\text { Total } \\
\text { breaks } \\
(\% / 0)\end{array}$} & \multirow{3}{*}{$\begin{array}{c}\text { Total } \\
\text { aber- } \\
\text { rations } \\
(\%)\end{array}$} \\
\hline & & & & \multicolumn{2}{|c|}{ Gaps } & \multicolumn{2}{|c|}{ Breaks } & & & \\
\hline & & & & $\begin{array}{c}\text { Chroma- } \\
\text { tid } \\
\text { (N) }\end{array}$ & $\begin{array}{l}\text { Iso- } \\
\text { locus } \\
\text { (N) }\end{array}$ & $\begin{array}{l}\text { Chroma- } \\
\text { tid } \\
\text { (N) }\end{array}$ & $\begin{array}{l}\text { Iso- } \\
\text { locus } \\
\text { (N) }\end{array}$ & & & \\
\hline \multicolumn{11}{|l|}{ Smokers } \\
\hline $\begin{array}{lr}\text { Subject } & 8 \\
\text { Subject } & 6 \\
\text { Subject } & 19 \\
\text { Subject } & 32 \\
\text { Subject } & 40 \\
\text { Subject } & 47\end{array}$ & $\begin{array}{l}44 \\
51 \\
49 \\
34 \\
31 \\
35\end{array}$ & $\begin{array}{r}18 \\
28 \\
23 \\
15 \\
7 \\
9\end{array}$ & $\begin{array}{l}4.5 \\
9.5 \\
4.0 \\
9.0 \\
6.0 \\
4.5\end{array}$ & $\begin{array}{r}6 \\
12 \\
5 \\
3 \\
6 \\
3\end{array}$ & $\begin{array}{l}0 \\
1 \\
1 \\
5 \\
1 \\
4\end{array}$ & $\begin{array}{l}2 \\
0 \\
1 \\
6 \\
3 \\
1\end{array}$ & $\begin{array}{c}1 \\
12 \\
1 \\
7 \\
2 \mathrm{a} \\
1\end{array}$ & $\begin{array}{l}3.0 \\
6.5 \\
3.0 \\
4.0 \\
3.5 \\
3.5\end{array}$ & $\begin{array}{l}1.5 \\
6.0 \\
1.0 \\
6.5 \\
2.5 \\
1.0\end{array}$ & $\begin{array}{r}4.5 \\
12.5 \\
4.0 \\
10.5 \\
6.0 \\
4.5\end{array}$ \\
\hline \multicolumn{11}{|l|}{ Nonsmokers } \\
\hline $\begin{array}{ll}\text { Subject } & 16 \\
\text { Subject } & 12 \\
\text { Subject } 23 \\
\text { Subject } 109 \\
\text { Subject } 42 \\
\text { Subject } & 37\end{array}$ & $\begin{array}{l}31 \\
46 \\
42 \\
39 \\
30 \\
31\end{array}$ & $\begin{array}{r}11 \\
11 \\
17 \\
15 \\
11 \\
8\end{array}$ & $\begin{array}{r}10.5 \\
5.0 \\
4.0 \\
5.5 \\
10.5 \\
7.0\end{array}$ & $\begin{array}{r}12 \\
3 \\
3 \\
3 \\
12 \\
8\end{array}$ & $\begin{array}{l}4 \\
0 \\
0 \\
1 \\
3 \\
0\end{array}$ & $\begin{array}{l}3 \\
1 b \\
1 \\
2 \\
3 \\
5\end{array}$ & $\begin{array}{l}6 \\
6 \\
4 \\
6 \\
4^{c} \mathrm{c} \\
2\end{array}$ & $\begin{array}{l}8.0 \\
1.5 \\
1.5 \\
2.0 \\
7.5 \\
4.0\end{array}$ & $\begin{array}{l}4.5 \\
3.5 \\
2.5 \\
4.0 \\
3.5 \\
3.5\end{array}$ & $\begin{array}{r}12.5 \\
5.0 \\
4.0 \\
6.0 \\
11.0 \\
7.5\end{array}$ \\
\hline
\end{tabular}

a One dicentric chromosome.

$b$ Interchange.

c Two dicentric chromosomes.

Table 2. Chromosome aberrations in the drivers of gasoline vehicles (group 2); 200 cells were analyzed from each subject.

\begin{tabular}{|c|c|c|c|c|c|c|c|c|c|}
\hline \multirow{3}{*}{$\begin{array}{l}\text { Age } \\
\text { (a) }\end{array}$} & \multirow{3}{*}{$\begin{array}{c}\text { Time } \\
\text { in job } \\
\text { (a) }\end{array}$} & \multirow{3}{*}{$\begin{array}{c}\text { Cells } \\
\text { with } \\
\text { aberr- } \\
\text { rations } \\
(\%)\end{array}$} & \multicolumn{4}{|c|}{ Type of aberration } & \multirow{3}{*}{$\begin{array}{l}\text { Total } \\
\text { gaps } \\
(\%)\end{array}$} & \multirow{3}{*}{$\begin{array}{c}\text { Total } \\
\text { breaks } \\
(\%)\end{array}$} & \multirow{3}{*}{$\begin{array}{c}\text { Total } \\
\text { aber- } \\
\text { rations } \\
(\%)\end{array}$} \\
\hline & & & \multicolumn{2}{|c|}{ Gaps } & \multicolumn{2}{|c|}{ Breaks } & & & \\
\hline & & & $\begin{array}{c}\text { Chroma- } \\
\text { tid } \\
\text { (N) }\end{array}$ & $\begin{array}{l}\text { Iso- } \\
\text { locus } \\
\text { (N) }\end{array}$ & $\begin{array}{c}\text { Chroma- } \\
\text { tid } \\
\text { (N) }\end{array}$ & $\begin{array}{l}\text { Iso- } \\
\text { locus } \\
\text { (N) }\end{array}$ & & & \\
\hline
\end{tabular}

\section{Smokers}

\begin{tabular}{lrrrrrrrrrr} 
Subject 21 & 39 & 15 & 11.5 & 14 & 1 & 5 & 4 & 7.5 & 4.5 & 12.0 \\
Subject 105 & 56 & 20 & 6.5 & 8 & 1 & 1 & 8 & 4.5 & 4.5 & 9.0 \\
Subject 101 & 46 & 9 & 7.5 & 6 & 5 & 1 & 5 & 5.5 & 3.0 & 8.5 \\
Subject 26 & 30 & 10 & 2.5 & 0 & 0 & 2 & 3 & 0.0 & 2.5 & 2.5 \\
Subject 31 & 36 & 11 & 9.5 & 9 & 6 & 1 & 3 & 7.5 & 2.0 & 9.5 \\
Subject 48 a & 29 & 3 & 7.0 & 5 & 2 & 5 & 5 & 3.5 & 5.0 & 8.5 \\
Nonsmokers & & & & & & & & & & \\
Subject 2 & 28 & $6-10$ & 2.0 & 2 & 1 & 1 & 0 & 1.5 & 0.5 & 2.0 \\
Subject 103 & 40 & 11 & 5.5 & 6 & 0 & 3 & 3 & 3.0 & 3.0 & 6.0 \\
Subject 18 & 43 & 27 & 5.0 & 9 & 0 & 1 & 0 & 4.5 & 0.5 & 5.0 \\
Subject 27 & 38 & 16 & 2.5 & 3 & 0 & 0 & 2 & 1.5 & 1.0 & 2.5 \\
Subject 44 & 30 & 3 & 6.0 & 8 & 2 & 1 & 1 & 5.0 & 1.0 & 6.0 \\
Subject 35 & 35 & 14 & 5.0 & 6 & 0 & 5 & 0 & 3.0 & 2.5 & 5.5 \\
\hline
\end{tabular}

a $46 / 47$ mosaic; $82.5 \%$ of the cells with an extra chromosome $\{i(15 p) ?\}$. 
chromosomes or that it is an isochromosome for any of these. It seems very unlikely that the origin of this small chromosome can be attributed to exposure to automobile exhaust gases.

\section{Sister chromatid exchanges}

Table 5 shows the mean number of SCEs from the analyses of 20 cells taken from each subject, together with the standard

Table 3. Chromosome aberrations in the automobile inspectors (group 3); 200 cells were analyzed from each subject.

\begin{tabular}{|c|c|c|c|c|c|c|c|c|c|c|}
\hline & \multirow{3}{*}{$\begin{array}{c}\text { Age } \\
\text { (a) }\end{array}$} & \multirow{3}{*}{$\begin{array}{c}\text { Time } \\
\text { in job } \\
(a)\end{array}$} & \multirow{3}{*}{$\begin{array}{l}\text { Cells } \\
\text { with } \\
\text { aberr- } \\
\text { rations } \\
(\%)\end{array}$} & \multicolumn{4}{|c|}{ Type of aberration } & \multirow{3}{*}{$\begin{array}{l}\text { Total } \\
\text { gaps } \\
(\%)\end{array}$} & \multirow{3}{*}{$\begin{array}{c}\text { Total } \\
\text { breaks } \\
(\%)\end{array}$} & \multirow{3}{*}{$\begin{array}{c}\text { Total } \\
\text { aber- } \\
\text { rations } \\
(\%)\end{array}$} \\
\hline & & & & \multicolumn{2}{|c|}{ Gaps } & \multicolumn{2}{|c|}{ Breaks } & & & \\
\hline & & & & $\begin{array}{l}\text { Chroma- } \\
\text { tid } \\
\text { (N) }\end{array}$ & $\begin{array}{l}\text { Iso- } \\
\text { locus } \\
\text { (N) }\end{array}$ & $\begin{array}{c}\text { Chroma- } \\
\text { tid } \\
\text { (N) }\end{array}$ & $\begin{array}{l}\text { Iso- } \\
\text { locus } \\
\text { (N) }\end{array}$ & & & \\
\hline \multicolumn{11}{|l|}{ Smokers } \\
\hline $\begin{array}{lr}\text { Subject } & 17 \\
\text { Subject } & 11 \\
\text { Subject } & 5 \\
\text { Subject } & 34 \\
\text { Subject } & 46 \\
\text { Subject } & 39\end{array}$ & $\begin{array}{l}47 \\
46 \\
44 \\
33 \\
32 \\
34\end{array}$ & $\begin{array}{r}9 \\
8 \\
3 \\
9 \\
2 \\
12\end{array}$ & $\begin{array}{l}4.5 \\
9.5 \\
9.0 \\
8.0 \\
8.0 \\
9.0\end{array}$ & $\begin{array}{r}4 \\
11 \\
16 \\
3 \\
10 \\
12\end{array}$ & $\begin{array}{l}0 \\
1 \\
2 \\
4 \\
3 \\
5\end{array}$ & $\begin{array}{l}3 \\
1 \\
4 \\
8 \\
2 \\
2\end{array}$ & $\begin{array}{l}3 \\
6 \\
1 \\
4 \\
3 \\
0\end{array}$ & $\begin{array}{l}2.0 \\
6.0 \\
9.0 \\
3.5 \\
6.5 \\
8.5\end{array}$ & $\begin{array}{l}3.0 \\
3.5 \\
2.5 \\
6.0 \\
2.5 \\
1.0\end{array}$ & $\begin{array}{r}5.0 \\
9.5 \\
11.5 \\
9.5 \\
9.0 \\
9.5\end{array}$ \\
\hline \multicolumn{11}{|l|}{ Nonsmokers } \\
\hline $\begin{array}{lr}\text { Subject } 4 \\
\text { Subject } 24 \\
\text { Subject } 22 \\
\text { Subject } 38 \\
\text { Subject } 28 \\
\text { Subject } 43\end{array}$ & $\begin{array}{l}34 \\
35 \\
37 \\
31 \\
32 \\
30\end{array}$ & $\begin{array}{r}5 \\
12 \\
13 \\
6 \\
3 \\
8\end{array}$ & $\begin{array}{l}0.5 \\
4.0 \\
3.5 \\
2.0 \\
8.5 \\
8.5\end{array}$ & $\begin{array}{r}0 \\
7 \\
3 \\
1 \\
10 \\
11\end{array}$ & $\begin{array}{l}0 \\
0 \\
0 \\
2 \\
2 \\
1\end{array}$ & $\begin{array}{l}0 \\
0 \\
2 \\
0 \\
3 \\
5\end{array}$ & $\begin{array}{l}1 \mathrm{a} \\
1 \\
2 \\
1 \mathrm{a} \\
4 \mathrm{a} \\
2\end{array}$ & $\begin{array}{l}0.0 \\
3.5 \\
1.5 \\
1.5 \\
6.0 \\
6.0\end{array}$ & $\begin{array}{l}0.5 \\
0.5 \\
2.0 \\
0.5 \\
3.5 \\
3.5\end{array}$ & $\begin{array}{l}0.5 \\
4.0 \\
3.5 \\
2.0 \\
9.5 \\
9.5\end{array}$ \\
\hline
\end{tabular}

a One dicentric chromosome.

Table 4. Chromosome aberrations in the referents (group 4); 200 cells were analyzed from each subject.

\begin{tabular}{|c|c|c|c|c|c|c|c|c|c|}
\hline \multirow{3}{*}{$\begin{array}{l}\text { Age } \\
\text { (a) }\end{array}$} & \multirow{3}{*}{$\begin{array}{l}\text { Time } \\
\text { in job } \\
\text { (a) }\end{array}$} & \multirow{3}{*}{$\begin{array}{c}\text { Cells } \\
\text { with } \\
\text { aberr- } \\
\text { rations } \\
(\%)\end{array}$} & \multicolumn{4}{|c|}{ Type of aberration } & \multirow{3}{*}{$\begin{array}{l}\text { Total } \\
\text { gaps } \\
(\%)\end{array}$} & \multirow{3}{*}{$\begin{array}{c}\text { Total } \\
\text { breaks } \\
(\%)\end{array}$} & \multirow{3}{*}{$\begin{array}{c}\text { Total } \\
\text { aber- } \\
\text { rations } \\
(\%)\end{array}$} \\
\hline & & & \multicolumn{2}{|c|}{ Gaps } & \multicolumn{2}{|c|}{ Breaks } & & & \\
\hline & & & $\begin{array}{c}\text { Chroma- } \\
\text { tid } \\
\text { (N) }\end{array}$ & $\begin{array}{l}\text { Iso- } \\
\text { locus } \\
\text { (N) }\end{array}$ & $\begin{array}{l}\text { Chroma- } \\
\text { tid } \\
\text { (N) }\end{array}$ & $\begin{array}{l}\text { Iso- } \\
\text { locus } \\
\text { (N) }\end{array}$ & & & \\
\hline
\end{tabular}

\begin{tabular}{|c|c|c|c|c|c|c|c|c|c|c|}
\hline \multicolumn{11}{|l|}{ Smokers } \\
\hline Subject & 37 & 8 & 10.0 & 14 & 3 & 3 & 2 & 8.5 & 2.5 & 11.0 \\
\hline Subject & 53 & 5 & 4.0 & 1 & 0 & 4 & 5 & 0.5 & 4.5 & 5.0 \\
\hline Subject 1 & 52 & 12 & 13.5 & 14 & 1 & 3 & 11 & 7.5 & 7.0 & 14.5 \\
\hline Subject 3 & 34 & 17 & 7.5 & 11 & 2 & 2 & 3 & 6.5 & 2.5 & 9.0 \\
\hline Subject 4 & 28 & 4 & 3.5 & 2 & 0 & 2 & 3 & 1.0 & 2.5 & 3.5 \\
\hline Subject 3 & 24 & 7 & 3.0 & 2 & 1 & 1 & 2 & 1.5 & 1.5 & 3.0 \\
\hline \multicolumn{11}{|l|}{ Nonsmokers } \\
\hline Subject & 35 & 4 & 3.5 & 5 & 0 & 1 & 1 & 2.5 & 1.0 & 3.5 \\
\hline Subject 7 & 44 & 20 & 2.0 & 0 & 1 & 2 & 1 & 0.5 & 1.5 & 2.0 \\
\hline Subject 13 & 42 & 26 & 3.5 & 3 & 1 & 2 & 2 & 2.0 & 2.0 & 4.0 \\
\hline Subject 36 & 36 & 9 & 6.0 & 11 & 2 & 2 & 0 & 6.5 & 1.0 & 7.5 \\
\hline Subject 25 & 27 & 5 & 1.0 & 1 & 0 & 0 & 1 & 0.5 & 0.5 & 1.0 \\
\hline Subject 45 & 26 & 2 & 8.0 & 11 & 1 & 4 & 1 & 6.0 & 2.5 & 8.5 \\
\hline
\end{tabular}


Table 5. Frequency of sister chromatid exchanges (SCEs) in the four groups under study. Twenty cells were analyzed for each subject, and the entries in the table are the means and standard deviations of the number of SCEs/cell observed.

\begin{tabular}{|c|c|c|c|c|c|c|c|c|c|c|c|c|c|c|}
\hline \multicolumn{4}{|c|}{$\begin{array}{c}\text { Diesel vehicle } \\
\text { drivers }\end{array}$} & \multicolumn{3}{|c|}{$\begin{array}{c}\text { Gasoline vehicle } \\
\text { drivers }\end{array}$} & \multicolumn{4}{|c|}{$\begin{array}{l}\text { Automobile } \\
\text { inspectors }\end{array}$} & \multicolumn{4}{|c|}{ Referents } \\
\hline & & Mean & $S D$ & & Mean & $\mathrm{SD}$ & & & Mean & SD & & & Mean & SD \\
\hline \multicolumn{4}{|l|}{ Smokers } & \multicolumn{3}{|l|}{ Smokers } & \multicolumn{4}{|l|}{ Smokers } & \multicolumn{4}{|l|}{ Smokers } \\
\hline $\begin{array}{l}\text { Subject } \\
\text { Subject } \\
\text { Subject } \\
\text { Subject } \\
\text { Subject } \\
\text { Subject }\end{array}$ & $\begin{array}{r}8 \\
6 \\
19 \\
32 \\
40 \\
47\end{array}$ & $\begin{array}{r}7.80 \\
12.15 \\
8.80 \\
14.85 \\
5.05 \\
14.10\end{array}$ & $\begin{array}{l}5.62 \\
4.15 \\
2.46 \\
4.26 \\
2.06 \\
7.27\end{array}$ & $\begin{array}{lr}\text { Subject } & 21 \\
\text { Subject } & 105 \\
\text { Subject } & 101 \\
\text { Subject } & 26 \\
\text { Subject } & 31 \\
\text { Subject } & 48\end{array}$ & $\begin{array}{r}12.75 \\
10.35 \\
12.65 \\
9.85 \\
10.95 \\
8.60\end{array}$ & $\begin{array}{l}3.48 \\
4.86 \\
9.21 \\
3.54 \\
4.01 \\
2.52\end{array}$ & $\begin{array}{l}\text { Subject } \\
\text { Subject } \\
\text { Subject } \\
\text { Subject } \\
\text { Subject } \\
\text { Subject }\end{array}$ & $\begin{array}{r}17 \\
11 \\
5 \\
34 \\
46 \\
39\end{array}$ & $\begin{array}{r}11.65 \\
10.00 \\
10.40 \\
10.05 \\
9.50 \\
8.05\end{array}$ & $\begin{array}{l}4.25 \\
3.03 \\
3.72 \\
3.87 \\
2.33 \\
2.27\end{array}$ & $\begin{array}{l}\text { Subject } \\
\text { Subject } \\
\text { Subject } \\
\text { Subject } \\
\text { Subject } \\
\text { Subject }\end{array}$ & $\begin{array}{r}9 \\
1 \\
15 \\
33 \\
41 \\
30\end{array}$ & $\begin{array}{l}8.95 \\
9.30 \\
9.30 \\
8.95 \\
7.65 \\
7.20\end{array}$ & $\begin{array}{l}2.63 \\
5.43 \\
3.51 \\
3.07 \\
2.41 \\
2.59\end{array}$ \\
\hline \multicolumn{2}{|c|}{ All smokers } & 10.46 & 4.66 & $\begin{array}{l}\text { All smokers } \\
\text { Nonsmokers }\end{array}$ & 10.86 & 5.09 & \multicolumn{2}{|c|}{$\begin{array}{l}\text { All smokers } \\
\text { Nonsmokers }\end{array}$} & 9.94 & 3.35 & \multicolumn{2}{|c|}{$\begin{array}{l}\text { All smokers } \\
\text { Nonsmokers }\end{array}$} & 8.56 & 3.43 \\
\hline $\begin{array}{l}\text { Subject } \\
\text { Subject } \\
\text { Subject } \\
\text { Subject } 1 \\
\text { Subject } \\
\text { Subject }\end{array}$ & $\begin{array}{r}16 \\
12 \\
23 \\
109 \\
42 \\
37\end{array}$ & $\begin{array}{r}11.55 \\
7.00 \\
7.10 \\
6.35 \\
8.00 \\
6.55\end{array}$ & $\begin{array}{l}3.22 \\
3.23 \\
2.75 \\
3.27 \\
2.66 \\
3.07\end{array}$ & $\begin{array}{lr}\text { Subject } & 2 \\
\text { Subject } & 103 \\
\text { Subject } & 18 \\
\text { Subject } & 27 \\
\text { Subject } & 44 \\
\text { Subject } & 35\end{array}$ & $\begin{array}{r}5.00 \\
7.15 \\
5.85 \\
6.35 \\
11.60 \\
9.40\end{array}$ & $\begin{array}{l}2.66 \\
3.62 \\
2.28 \\
2.30 \\
3.78 \\
3.27\end{array}$ & $\begin{array}{l}\text { Subject } \\
\text { Subject } \\
\text { Subject } \\
\text { Subject } \\
\text { Subject } \\
\text { Subject }\end{array}$ & $\begin{array}{r}4 \\
24 \\
22 \\
38 \\
28 \\
43\end{array}$ & $\begin{array}{l}9.65 \\
8.15 \\
6.95 \\
6.55 \\
6.95 \\
6.10\end{array}$ & $\begin{array}{l}3.28 \\
4.17 \\
2.96 \\
2.48 \\
2.61 \\
3.08\end{array}$ & $\begin{array}{l}\text { Subject } \\
\text { Subject } \\
\text { Subject } \\
\text { Subject } \\
\text { Subject } \\
\text { Subject }\end{array}$ & $\begin{array}{r}3 \\
7 \\
13 \\
36 \\
25 \\
45\end{array}$ & $\begin{array}{l}9.15 \\
6.30 \\
7.00 \\
7.75 \\
5.60 \\
7.80\end{array}$ & $\begin{array}{l}4.34 \\
3.23 \\
4.36 \\
2.73 \\
2.80 \\
2.46\end{array}$ \\
\hline $\begin{array}{l}\text { All } \\
\text { nonsmoke }\end{array}$ & ters & 7.76 & 2.73 & $\begin{array}{l}\text { All } \\
\text { nonsmokers }\end{array}$ & 7.56 & 3.06 & $\begin{array}{l}\text { All } \\
\text { nonsmok }\end{array}$ & kers & 7.39 & 3.15 & $\begin{array}{l}\text { All } \\
\text { nonsmok }\end{array}$ & kers & 7.27 & 3.41 \\
\hline
\end{tabular}

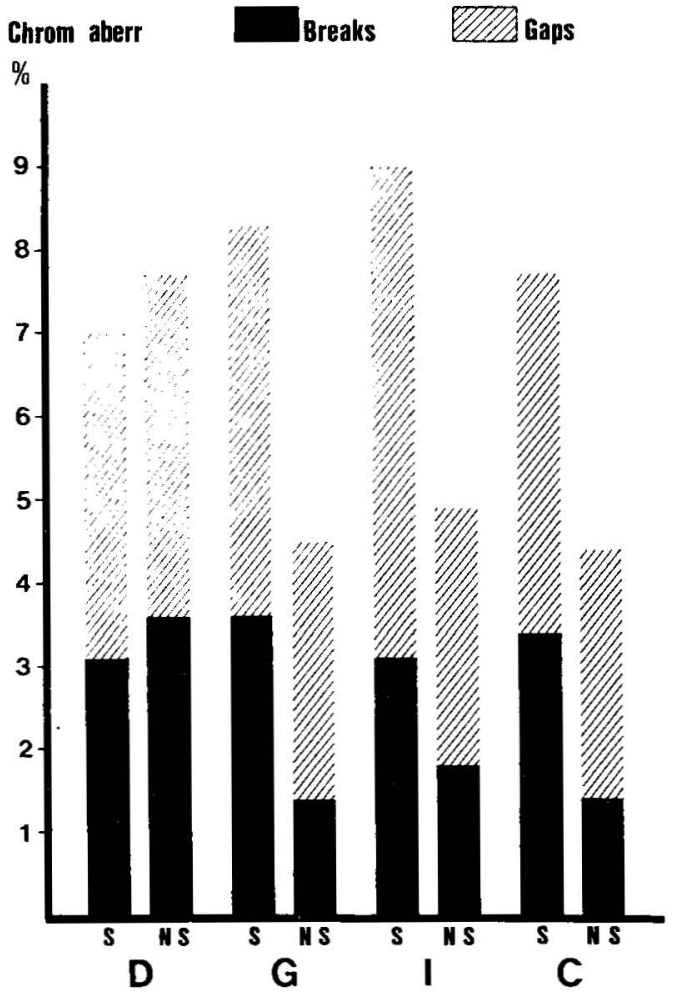

Fig 1. Diagrammatic representation of chromosome aberrations (chrom aberr) in the four occupational groups, divided into smokers (S) and nonsmokers (NS). ( $D=$ diesel vehicle drivers, $\mathrm{G}=$ gasoline vehicle drivers, $\mathbf{I}=$ automobile inspectors, $\mathrm{C}=$ referents)
No SCEs / cell (mean of 20 cells)

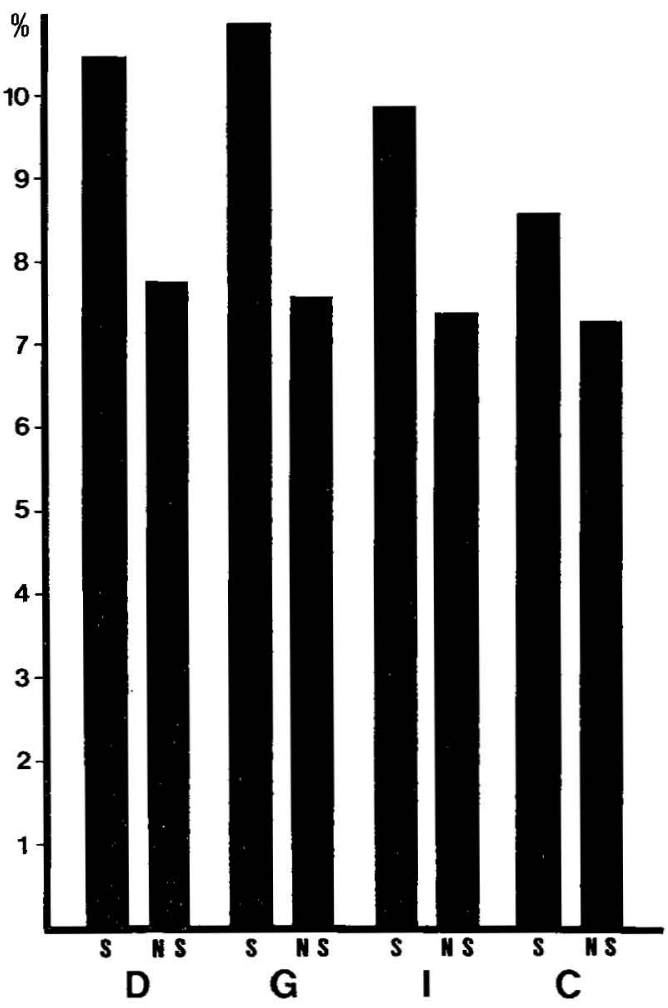

Fig 2. Diagrammatic representation of sister chromatid exchanges (SCEs) in the four occupational groups, divided into smokers (S) and nonsmokers (NS). ( $D=$ diesel vehicle drivers, $\mathrm{G}=$ gasoline vehicle drivers, $\quad \mathbf{I}=$ automobile inspectors, $\mathrm{C}=$ referents) 
deviations of the observations. The subjects were divided into their occupational groups and into smokers and nonsmokers. The table also shows the mean SCEs per cell for each of these eight groups. These means vary from 7.3 for the nonsmoking referents to 10.9 for the gasoline vehicle drivers that smoke. The results are included in table 6 and shown in fig 2 .

\section{Analyses}

The following three measurements of chromosome changes were applied in the study of the possible effects of the environment and smoking on the 48 subjects: (i) the total frequency of chromatid and isochromatid breaks per 100 cells, (ii) the total frequency of aberrations (breaks + gaps) per 100 cells, and (iii) the mean number of SCEs per cell. In the text and in the tables these measurements have been designated as breaks, aberrations, and SCEs, respectively. Other factors such as age, length of employment, etc, have not been specially studied, but they were taken into consideration in the matching of the occupational groups. The matched individuals occupy corresponding places in tables $1-5$. The results have been summarized in table 6 in order to facilitate comparisons.

\section{Effect of occupation}

The investigation was planned to test two slightly different hypotheses: (i) whether the work environment of the drivers of diesel vehicles leads to a higher incidence of chromosome changes among these workers than that observed for other occupational groups (a comparison of group 1 versus groups 2-4) and (ii) whether those working in a traffic and vehicle environment, irrespective of the nature of the fuel involved, have a higher incidence of chromosome changes than that of a reference group (groups $1-3$ versus group 4).

Comparisons between the groups for each of the three kinds of measurements were made with the nonparametric method described in the Subjects and Methods section; this test is designed to ascertain whether or not a difference between a specified group, relative to the three other matched groups, can be attributed to chance. In these tests smokers were compared with smokers and nonsmokers with nonsmokers since the subjects were matched. In addition to these tests on the whole sample, we also tested the subgroups of smokers and nonsmokers separately, as it is possible that the effects of occupation may be apparent only among smokers (due to synergism) or nonsmokers (due to an effect of the work environment being hidden by smoking).

Thus altogether 18 tests were performed to investigate the effects of the work environment (three kinds of measurements used for investigating two hypotheses over two subgroups plus the whole sample). The results are summarized in table 7 .

The tests confirmed what is obvious from the summarized data in table 6 and fig 1 and 2, namely, that there is no strong effect of any of the work environments studied on the frequency of chromosome changes. Not a single test concerning the frequency of aberrations gave an associated probability value smaller than $5 \%$. The frequency of SCES among smokers indicated that the personnel working with vehicles had a higher frequency of SCEs than the referents, but the tendency was weak and may well have been due to chance.

The strongest sign of an effect of the work environment was the frequency of breaks in that the drivers of diesel vehicles had significantly more breaks than other workers. Smoking, however, was an important confounding factor since a significant effect of diesel exposure was only observed among the nonsmokers. No significant effect was found when any of the other measurements of chromosome changes were used.

The conclusion we have drawn from this investigation concerning the effect of the work environment on chromosome changes is that there remains a grave suspicion that working with diesel motors may cause an increased level of chromosome changes.

\section{Effect of smoking}

There is a clear indication in tables $1-6$ and in fig 1 and 2 that smoking affects the level of chromosome changes. The effect of smoking was tested within the different occupational groups by the Mann- 
Whitney U-test, and the results are shown in table 8. Of the 12 tests performed, six showed that the smokers had significantly more chromosome changes than the nonsmokers. Of the remaining six comparisons, which did not yield significant results, four had an associated probability value smaller than 0.15 . Only among the diesel drivers were results obtained which went against the general trend. For them the frequencies of breaks and aberrations were higher among the nonsmokers than among the smokers. The frequency of SCEs was, however, higher among the smokers than among the nonsmokers (with an associated probability value of 0.09 ).

The conclusion is clear. There is an obvious effect of smoking on chromosome changes, irrespective of which measurement is used for estimating the chromosome changes. The effect of smoking is greater than any possible effect of the

Table 6. Summary of the data in tables 1-5. The subjects are grouped according to their matched pair in each of the four study groups, smokers and nonsmokers separately. Gaps and breaks are given as the number per 100 cells, and sister chromatid exchanges (SCEs) as the number per cell (mean of 20 cells).

\begin{tabular}{|c|c|c|c|c|c|c|c|c|}
\hline & \multicolumn{4}{|c|}{ Smokers } & \multicolumn{4}{|c|}{ Nonsmokers } \\
\hline & $\begin{array}{l}\text { Diesel } \\
\text { vehicle } \\
\text { drivers }\end{array}$ & $\begin{array}{l}\text { Gasoline } \\
\text { vehicle } \\
\text { drivers }\end{array}$ & $\begin{array}{l}\text { Automo- } \\
\text { bile } \\
\text { inspec- } \\
\text { tors }\end{array}$ & $\begin{array}{l}\text { Refer- } \\
\text { ents }\end{array}$ & $\begin{array}{l}\text { Diesel } \\
\text { vehicle } \\
\text { drivers }\end{array}$ & $\begin{array}{l}\text { Gasoline } \\
\text { vehicle } \\
\text { drivers }\end{array}$ & $\begin{array}{l}\text { Automo- } \\
\text { bile } \\
\text { inspec- } \\
\text { tors }\end{array}$ & $\begin{array}{l}\text { Refer- } \\
\text { ents }\end{array}$ \\
\hline Matched subject & 8 & 21 & 17 & 9 & 16 & 2 & 4 & 3 \\
\hline $\begin{array}{l}\text { Gaps } \\
\text { Breaks } \\
\text { SCEs }\end{array}$ & $\begin{array}{l}3.0 \\
1.5 \\
7.80\end{array}$ & $\begin{array}{c}7.5 \\
4.5 \\
12.75\end{array}$ & $\begin{array}{c}2.0 \\
3.0 \\
11.65\end{array}$ & $\begin{array}{l}8.5 \\
2.5 \\
8.95\end{array}$ & $\begin{array}{c}8.0 \\
4.5 \\
11.55\end{array}$ & $\begin{array}{l}1.5 \\
0.5 \\
5.00\end{array}$ & $\begin{array}{l}0.0 \\
0.5 \\
9.65\end{array}$ & $\begin{array}{l}2.5 \\
1.0 \\
9.15\end{array}$ \\
\hline Matched subject & 6 & 105 & 11 & 1 & 12 & 103 & 24 & 7 \\
\hline $\begin{array}{l}\text { Gaps } \\
\text { Breaks } \\
\text { SCEs }\end{array}$ & $\begin{array}{c}6.5 \\
6.0 \\
12.15\end{array}$ & $\begin{array}{c}4.5 \\
4.5 \\
10.35\end{array}$ & $\begin{array}{c}6.0 \\
3.5 \\
10.00\end{array}$ & $\begin{array}{l}0.5 \\
4.5 \\
9.30\end{array}$ & $\begin{array}{l}1.5 \\
3.5 \\
7.00\end{array}$ & $\begin{array}{l}3.0 \\
3.0 \\
7.15\end{array}$ & $\begin{array}{l}3.5 \\
0.5 \\
8.15\end{array}$ & $\begin{array}{l}0.5 \\
1.5 \\
6.30\end{array}$ \\
\hline Matched subject & 19 & 101 & 5 & 15 & 23 & 18 & 22 & 13 \\
\hline $\begin{array}{l}\text { Gaps } \\
\text { Breaks } \\
\text { SCEs }\end{array}$ & $\begin{array}{l}3.0 \\
1.0 \\
8.80\end{array}$ & $\begin{array}{c}5.5 \\
3.0 \\
12.65\end{array}$ & $\begin{array}{c}9.0 \\
2.5 \\
10.40\end{array}$ & $\begin{array}{l}7.5 \\
7.0 \\
9.30\end{array}$ & $\begin{array}{l}1.5 \\
2.5 \\
7.10\end{array}$ & $\begin{array}{l}4.5 \\
0.5 \\
5.85\end{array}$ & $\begin{array}{l}1.5 \\
2.0 \\
6.95\end{array}$ & $\begin{array}{l}2.0 \\
2.0 \\
7.00\end{array}$ \\
\hline Matched subject & 32 & 26 & 34 & 33 & 109 & 27 & 38 & 36 \\
\hline $\begin{array}{l}\text { Gaps } \\
\text { Breaks } \\
\text { SCEs }\end{array}$ & $\begin{array}{c}4.0 \\
6.5 \\
14.85\end{array}$ & $\begin{array}{l}0.0 \\
2.5 \\
9.85\end{array}$ & $\begin{array}{c}3.5 \\
6.0 \\
10.05\end{array}$ & $\begin{array}{l}6.5 \\
2.5 \\
8.95\end{array}$ & $\begin{array}{l}2.0 \\
4.0 \\
6.35\end{array}$ & $\begin{array}{l}1.5 \\
1.0 \\
6.35\end{array}$ & $\begin{array}{l}1.5 \\
0.5 \\
6.55\end{array}$ & $\begin{array}{l}6.5 \\
1.0 \\
7.75\end{array}$ \\
\hline Matched subject & 40 & 31 & 46 & 41 & 42 & 44 & 28 & 25 \\
\hline $\begin{array}{l}\text { Gaps } \\
\text { Breaks } \\
\text { SCEs }\end{array}$ & $\begin{array}{l}3.5 \\
2.5 \\
5.05\end{array}$ & $\begin{array}{c}7.5 \\
2.0 \\
10.95\end{array}$ & $\begin{array}{l}6.5 \\
2.5 \\
9.50\end{array}$ & $\begin{array}{l}1.0 \\
2.5 \\
7.65\end{array}$ & $\begin{array}{l}7.5 \\
3.5 \\
8.00\end{array}$ & $\begin{array}{c}5.0 \\
1.0 \\
11.60\end{array}$ & $\begin{array}{l}6.0 \\
3.5 \\
6.95\end{array}$ & $\begin{array}{l}0.5 \\
0.5 \\
5.60\end{array}$ \\
\hline Matched subject & 47 & 48 & 39 & 30 & 37 & 35 & 43 & 45 \\
\hline $\begin{array}{l}\text { Gaps } \\
\text { Breaks } \\
\text { SCEs }\end{array}$ & $\begin{array}{c}3.5 \\
1.0 \\
14.10\end{array}$ & $\begin{array}{l}3.5 \\
5.0 \\
8.60\end{array}$ & $\begin{array}{l}8.5 \\
1.0 \\
8.05\end{array}$ & $\begin{array}{l}1.5 \\
1.5 \\
7.20\end{array}$ & $\begin{array}{l}4.0 \\
3.5 \\
6.55\end{array}$ & $\begin{array}{l}3.0 \\
2.5 \\
9.40\end{array}$ & $\begin{array}{l}6.0 \\
3.5 \\
6.10\end{array}$ & $\begin{array}{l}6.0 \\
2.5 \\
7.80\end{array}$ \\
\hline \multicolumn{9}{|l|}{ Means } \\
\hline $\begin{array}{l}\text { Gaps } \\
\text { Breaks } \\
\text { SCEs }\end{array}$ & $\begin{array}{r}3.9 \\
3.1 \\
10.5\end{array}$ & $\begin{array}{r}4.7 \\
3.6 \\
10.9\end{array}$ & $\begin{array}{l}5.9 \\
3.1 \\
9.9\end{array}$ & $\begin{array}{l}4.3 \\
3.4 \\
8.6\end{array}$ & $\begin{array}{l}4.1 \\
3.6 \\
7.8\end{array}$ & $\begin{array}{l}3.1 \\
1.4 \\
7.6\end{array}$ & $\begin{array}{l}3.1 \\
1.8 \\
7.4\end{array}$ & $\begin{array}{l}3.0 \\
1.4 \\
7.3\end{array}$ \\
\hline
\end{tabular}


work environments studied.

No positive correlation was found between the chromosome changes and the tobacco consumption measured as cigarettes per day (table 9), but the data are not ideal for this calculation as only 4 of the 24 smokers belonged to the category of moderate smokers (less than 10 cigarettes/d).

\section{Relationship between sister chromatid exchanges and chromosome breaks}

In this investigation three different measurements were used to study the chromosome changes in an individual. Of these, the frequency of chromosome aberrations is naturally correlated with the frequency of chromosome breaks since every break is recorded as an aberration. In an effort to ascertain whether there was also a correlation between SCEs and breaks, the data from the 48 individuals from this investigation, and that from six others whose chromosomes were studied in a similar manner at the same time, were examined statistically.

In this sample of 54 individuals we found a weak but well established positive correlation between the frequency of SCEs and the frequency of breaks. Kendall's rank correlation coefficient was 0.26 , and the associated probability value lay between 0.001 and $0.01(27)$.

The relationship between chromosome aberrations and SCEs is visualized in fig 3. In this figure the frequency of total aberrations in an individual is expressed in "chromatid units," breaks and gaps of the isochromatid type being given the value 2 and breaks and gaps of the chromatid type receiving the value 1 .

\section{Discussion}

\section{Chromosome changes and occupation}

It is not possible, based on the present study, to conclude definitely whether oc-

Table 7. The effect of occupation on chromosome changes.

\begin{tabular}{|c|c|c|c|}
\hline & \multicolumn{3}{|c|}{ Basis of comparison } \\
\hline & Breaks & Aberrations & $\begin{array}{l}\text { Sister chromatid } \\
\text { exchanges }\end{array}$ \\
\hline $\begin{array}{l}\text { Hypothesis 1: group } 1 \text { versus groups } 2-4 \\
\text { Nonsmokers } \\
\text { Smokers } \\
\text { Whole sample }\end{array}$ & $\underset{* *}{* *}$ & $\begin{array}{l}\text { NS } \\
\text { NS } \\
\text { NS }\end{array}$ & $\begin{array}{l}\text { NS } \\
\text { NS } \\
\text { NS }\end{array}$ \\
\hline $\begin{array}{l}\text { Hypothesis 2: groups } 1-3 \text { versus group } 4 \\
\text { Nonsmokers } \\
\text { Smokers } \\
\text { Whole sample }\end{array}$ & $\begin{array}{l}\text { NS } \\
\text { NS } \\
\text { NS }\end{array}$ & $\begin{array}{l}\text { NS } \\
\text { NS } \\
\text { NS }\end{array}$ & $\begin{array}{l}\text { NS } \\
* \\
\text { NS }\end{array}$ \\
\hline
\end{tabular}

* $\mathrm{p}<0.05,{ }^{* *} \mathrm{p}<0.01$, NS $=$ not significant. (All tests have been performed "one-tailed.")

Table 8. The effect of smoking on chromosome changes.

\begin{tabular}{lccc}
\hline & \multicolumn{3}{c}{ Basis of comparison } \\
\cline { 2 - 4 } Occupational group & Breaks & Aberrations & $\begin{array}{c}\text { Sister chromatid } \\
\text { exchanges }\end{array}$ \\
\hline $\begin{array}{l}\text { Diesel vehicle drivers } \\
\text { Gasoline vehicle drivers }\end{array}$ & $\mathrm{NS}$ & $\mathrm{NS}$ & $\mathrm{NS}$ \\
$\begin{array}{l}\text { Automobile inspectors (mixed exposure) } \\
\text { Office workers (referents) }\end{array}$ & $\mathrm{NS}^{*}$ & ${ }^{*}$ & $*$ \\
\hline
\end{tabular}

${ }^{*} \mathrm{p}<0.05,{ }^{* *} \mathrm{p}<0.01, \mathrm{NS}=$ not significant. (All tests have been performed "one-tailed.") 
Table 9. Cigarette consumption and chromosome changes. Breaks and aberrations are given as the number per 100 cells, and sister chromatid exchanges as the number per cell (mean of 20 cells).

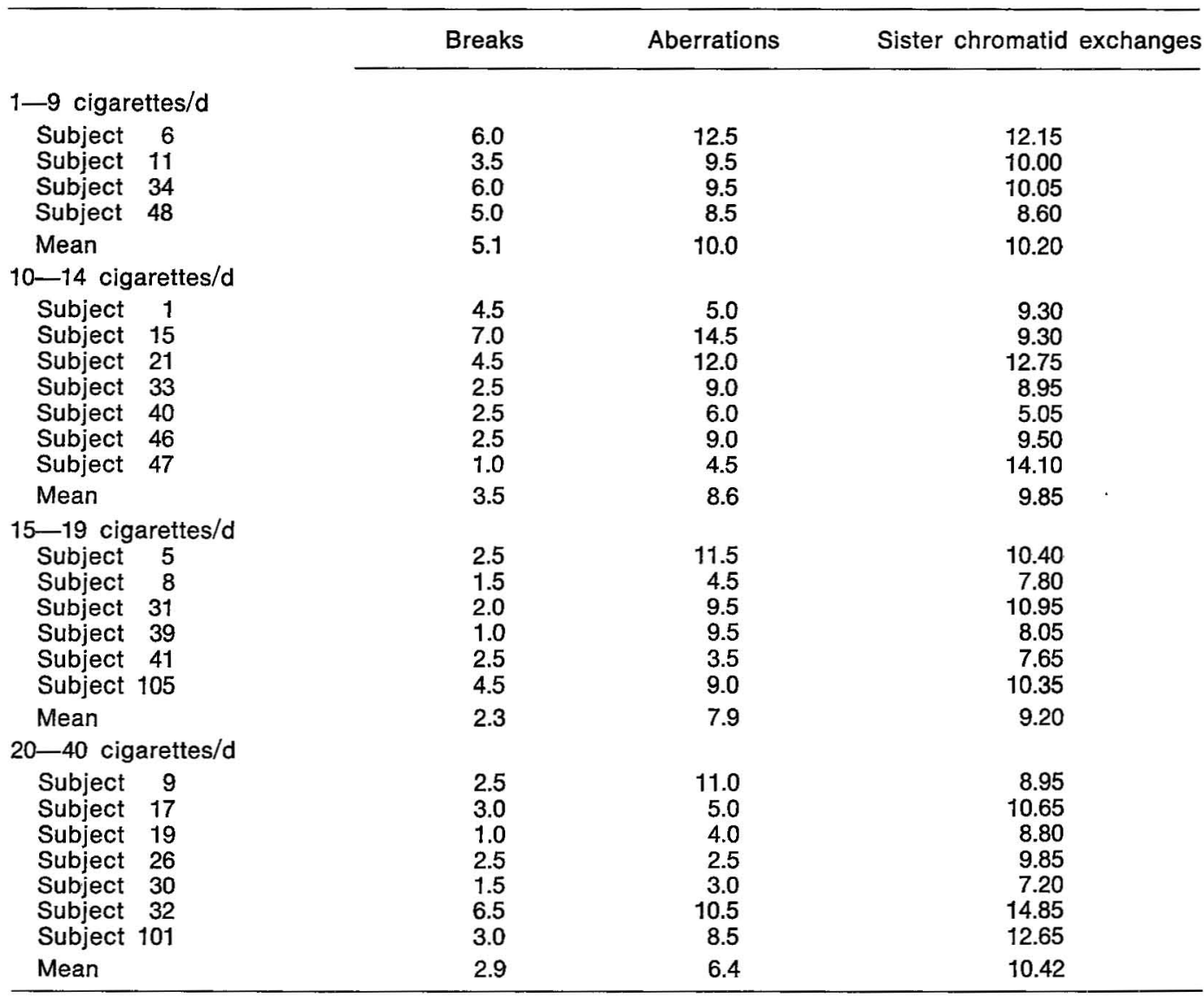

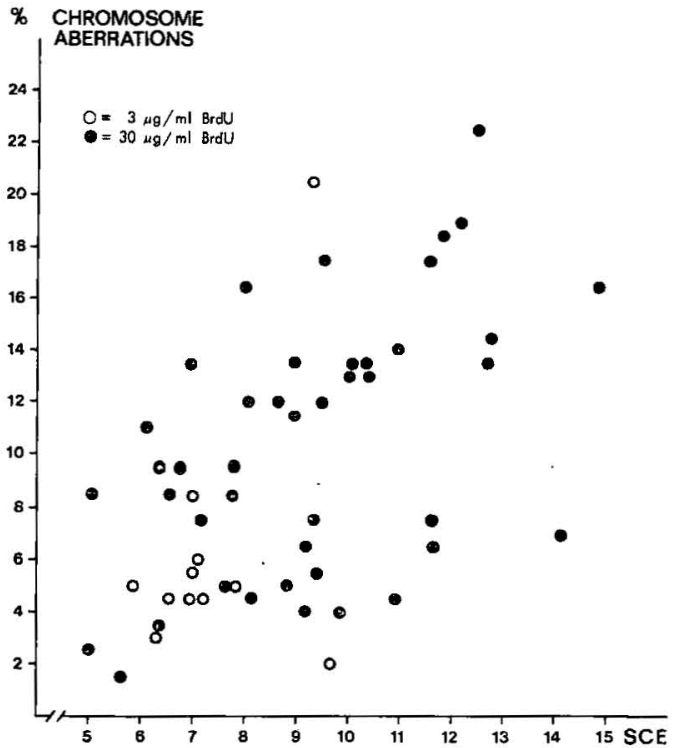

Fig 3. Relation between sister chromatid exchanges (mean number/cell) and chromosome aberrations (per 100 cells) for 54 subjects. The aberrations are expressed in "chromatid units"; the breaks and gaps of the isochromatid type have been given the value 2 , while breaks and gaps of the chromatid type have received the value 1 . 
cupational exposure to diesel exhaust causes an increase in chromosome changes in human lymphocytes. No significant change was revealed with regard to either frequency of aberrations or frequency of SCEs. However, a significant increase in the number of breaks (fig 1) was observed among the diesel-exposed nonsmokers. Among smokers no such effect could be shown. Since altogether 18 statistical significance tests were performed, there is an apparent risk that the observation of a higher frequency of chromosome breaks among the nonsmoking diesel-exposed drivers is a random one. We, however, feel that it is worth serious attention, even though a recent study by Nordenson et al (22) revealed no increased frequency of chromosome aberrations in miners exposed to diesel exhaust.

\section{Chromosome changes and smoking}

The present report presents conclusive evidence that chromosome changes are more frequent among smokers than among nonsmokers. At the time this investigation was made and first reported (8), no investigation appeared to have been undertaken to disclose any relation between damage and smoking in a normal population. Earlier publications on the effect of occupation on chromosome changes did not take smoking into consideration. More recently several papers have described or commented on the smoking habits of the experimental subjects, but the results of these investigations have been contradictory or difficult to interpret, probably because of the differing techniques that have been used to record the chromosome effects and the widely different categories of the subjects studied.

\section{Chromosome aberrations and smoking}

No increased incidence of chromosome breaks over that in a reference group was observed in smokers among laboratory staff (10), arsenic and lead workers (20, 21), toluene-exposed workers (19), and referents. There was however an indication of synergism between smoking and exposure to arsenic (20), and in miners and a reference group there was an increased frequency of both gaps and breaks among smokers (22). In a study of the frequency of dicentric and ring chromosomes and of chromatid translocations, a higher incidence was found in heavy smokers (40-60 cigarettes/d) than in an undefined reference group (23). In the present study an increased frequency of both breaks and total aberrations was found in three of the four occupational groups.

\section{Sister chromatid exchange and smoking}

The studies on smoking and the frequency of SCEs are also somewhat contradictory. Lambert et al (17), in a study of 18 psoriasis patients and 43 relevant referents, showed that not only do smokers have a higher SCE incidence than nonsmokers, but also that there is a stepwise increase of about $15 \%$ in the SCE frequency among moderate $(<10$ cigarettes/d) and heavy $(\geqslant 10$ cigarettes/d) smokers. Bala Krishna Murthy (3) also found a significant increase in the mean SCE frequency of smokers. Both the duration of smoking and the number of cigarettes smoked per day appeared to influence SCE frequency. More recently Hopkin \& Evans (14) and Husgafvel-Pursiainen et al (15) also reported a higher SCE frequency in smokers in comparison to nonsmokers.

In the present study we found an increased frequency of SCEs in the smokers of all four groups in comparison to the matched nonsmokers. The probability values were $0.09,<0.05,<0.01$, and 0.07 for diesel vehicle drivers, gasoline vehicle drivers, automobile inspectors, and referents, respectively.

On the other hand, no correlation between smoking and SCE incidence has been revealed in a number of studies $(2,7$, $13,17,29,30$ ).

The discrepancy between different investigations is obvious and usually difficult to explain. One explanation may be the conditions of lymphocyte cultivation, since variations in culture conditions greatly affect the frequency of SCEs (16). Factors influencing the considerable overlap in SCE frequency between smokers and nonsmokers and also between moderate and heavy smokers have been discussed by Hopkin \& Evans (14) and Lambert et al (16). Somewhat surprisingly, 
genetic factors do not seem to play any major role in the frequency and distribution of SCEs in normal subjects $(16,24)$.

We feel convinced that smoking is a potent etiologic factor in producing chromosome changes in the human population.

\section{Relationship between sister chromatid} exchanges and chromosome aberrations

In vitro studies on cultures of fibroblasts and human lymphocytes have shown that SCE measurements provide a very sensitive indicator for mutagenic and carcinogenic substances $(18,31)$. All of the 15 substances studied by Perry \& Evans (25) induced both SCEs and chromosome aberrations; a marked increase in the SCE frequency could be obtained at concentrations too low for the conventional methods of chromosome analysis. Moreover there exists a good dose-response relationship between the concentration of many genotoxic substances and SCE frequency (25), and a linear relation has been recorded between the number of SCEs and the number of mutations per cell in cultures of the Chinese hamster (6).

So far as we can trace, only a few other epidemiologic investigations have dealt with the relation between SCEs and chromosome breaks in a direct and quantitative manner. Hansteen et al (11) found no significant correlation for 16 polyvinyl chloride workers and 16 referents, and another study reported a negative correlation between SCEs and chromosome aberrations for female laboratory workers (10).

Data on both chromosome aberrations and SCEs were collected from 32 rotogravure workers exposed to toluene and 15 referents (19), but the results were not analyzed with respect to the correlation between aberrations and SCEs. However, smokers had a significantly higher SCE frequency than nonsmokers, whereas the rate of chromosome aberrations did not seem to be significantly increased among smokers.

We found a positive correlation between the frequency of SCEs and the frequency of chromosome breaks.

It appears urgent to throw further light on the question of the correlation between
SCEs and chromosome breaks, but it is probably too early to substitute SCE measurements for the more time-consuming conventional chromosome analyses before the underlying biochemical and genetic mechanisms have been revealed. It still seems appropriate to quote Savage (26) in this connection: "That SCEs constitute a highly sensitive test, and that agents differ in their ability to induce them is now established beyond reasonable doubt, but... it would seem unwise to substitute them completely for tests using conventional aberrations until more is understood of their relative genetic significance. Both would seem to be necessary at present [p 104]."

\section{Acknowledgments}

This work was supported by the Swedish Work Environment Fund.

We thank Dr J Gage for his constructive criticism in connection with the translation of the Swedish report into English.

\section{References}

1. Alves $\mathrm{P}$, Jonasson J. New staining method for the detection of sister-chromatid exchanges in BrdU-labelled chromosomes. J cell sci 32 (1978) 185-195.

2. Ardito G, Lamberti L, Ansaldi E, Ponzetto $P$. Sister-chromatid exchanges in cigarettesmoking human females and their newborns. Mutat res 78 (1980) 209-212.

3. Bala Krishna Murthy P. Frequency of sister chromatid exchanges in cigarette smokers. Hum genet 52 (1979) 343-345.

4. Berlin M, Gage JC, Gullberg B, Holm S, Knutsson $\mathrm{P}$, Tunek A. Breath concentration as an index of the health risk from benzene: Studies on the accumulation and clearance of inhaled benzene. Scand $\mathrm{j}$ work environ health 6 (1980) 104-111.

5. Buckton KE, Evans HJ. Methods for the analysis of human chromosome aberrations. World Health Organization, Geneva 1973.

6. Carrano AV, Thompson L.H, Lindh PA, Minkler JL. Sister chromatid exchange as an indicator of mutagenesis. Nature 271 (1978) $551-553$.

7. Crossen PE, Morgan WF. Sister chromatid exchange in cigarette smokers. Hum genet 53 (1980) 425-426.

8. Fredga $K$, Dävring L, Sunner M, Bengtsson BO, Elinder C-G, Sigtryggsson P, Berlin M. Kromosomförändringar hos arbetare exponerade för drivmedel och avgaser [Chromosome changes in workers exposed 
to motor fuels and their combustion residues]. Institutes of Genetics and Environmental Health, Lund 1979. (Report 79 0320 ).

9. Fredga K, Reitalu J, Berlin M. Chromosome studies in workers exposed to benzene. In: Berg $\mathrm{K}$, ed. Genetic damage in man caused by environmental agents. Academic Press, New York, NY 1979, pp $187-203$

10. Funes-Cravioto F, Zapata-Gayon C, Kolmodin-Hedman B, Lambert B, Lindsten J, Norberg E, Nordenskjöld $\mathbf{M}$, Olin R, Swensson A. Chromosome aberrations and sister-chromatid exchange in workers in chemical laboratories and a rotoprinting factory and in children of women laboratory workers. Lancet 2 (1977) 322-325.

11. Hansteen J-L, Hillestad L, This-Evensen E, Storetvedt Heldaas S. Effects of vinyl chloride in man: A cytogenetic follow-up study. Mutat res 51 (1978) 271-278.

12. Hemminki $K$, Sorsa M, Vainio $H$. Genetic risks caused by occupational chemicals. Scand j work environ health 5 (1979) $307-$ 327.

13. Hollander DH, Tockman MS, Liang YW, Borgaonkar DS, Frost JK. Sister-chromatid exchanges in the peripheral blood of cigarette smokers and in lung cancer patients; and the effect of chemotherapy. Hum genet 44 (1978) 165-171.

14. Hopkin JM, Evans HJ. Cigarette smokeinduced DNA damage and lung cancer risks. Nature 283 (1980) 388-390.

15. Husgafvel-Pursiainen $\mathrm{K}$, Mäki-Paakkanen J, Norppa H, Sorsa M. Smoking and sister chromatid exchange. Hereditas 92 (1980) $247-250$.

16. Lambert B, Lindblad A, Holmberg $\mathrm{K}$, Francesconi D. The use of sister chromatid exchange to monitor human populations for exposure to toxicologically harmful agents. In: Wolff $\mathrm{S}$, ed. Sister chromatid exchange. John Wiley \& Sons, New York, NY 1982, pp 149-182.

17. Lambert B, Lindblad A, Nordenskjöld $\mathbf{M}$, Werelius B. Increased frequency of sisterchromatid exchanges in cigarette smokers. Hereditas 88 (1978) 147-149.

18. Latt SA, Schreck RR. Sister chromatid exchange analysis. Am $\mathrm{j}$ hum genet 32 (1980) $297-313$.

19. Mäki-Paakkanen J, Husgafvel-Pursiainen K, Kalliomäki P-L, Tuominen J, Sorsa M. Toluene-exposed workers and chromosome aberrations. $\mathrm{J}$ toxicol environ health 6 (1980) $775-781$.

20. Nordenson I, Beckman G, Beckman L, Nordström S. Occupational and environmental risks in and around a smelter in northern Sweden: II Chromosomal aberrations in workers exposed to arsenic. Hereditas 88 (1978) 47-50.

21. Nordenson I, Beckman G, Beckman L, Nordström S. Occupational and environmental risks in and around a smelter in northern Sweden: IV Chromosomal aberrations in workers exposed to lead. Hereditas 88 (1978) 263-267.

22. Nordenson I, Sweins A, Dahlgren E, Beckman L. A study of chromosomal aberrations in miners exposed to diesel exhausts. Scand $j$ work environ health 7 (1981) $14-17$

23. Obe G, Herha J. Chromosomal aberrations in heavy smokers. Hum genet 41 (1978) $259-263$.

24. Pedersen C, Oláh E, Merrild U. Sister chromatid exchanges in cultured peripheral lymphocytes from twins. Hum genet 52 (1979) 281-294.

25. Perry P, Evans HJ. Cytological detection of mutagen-carcinogen exposure by sister chromatid exchange. Nature 258 (1975) 121-125.

26. Savage JRK. Chromosomal aberrations as tests for mutagenicity. Nature 258 (1975) $103-104$

27. Siegel S. Nonparametric statistics for the behavioral sciences. McGraw-Hill Kogakusha, Tokyo 1956.

28. Vigliani EC, Forni A. Benzene and leukemia. Environ res 11 (1976) 122-127.

29. Waksvik H, Klepp O, Brøgger A. Chromosome analyses of nurses handling cytostatic agents. Cancer treat rep 65 (1981) $607-610$.

30. Waksvik H, Magnus P, Berg K. Effects of age, sex and genes on sister chromatid exchange. Clin genet 20 (1981) $449-454$

31. Wolff S. Sister chromatid exchange: The most sensitive mammalian system for determining the effects of mutagenic carcinogens. In: Berg $\mathrm{K}$, ed. Genetic damage in man caused by environmental agents. Academic Press, New York, NY 1979, pp $229-246$.

Received for publication: 2 August 1981 